\title{
Religious Pluralism in Yan Martel's Life of Pi: A Case of Intertextual Correspondence with Swami Vivekananda's Religious Philosophy
}

John Kuriakose*

Department of Foreign Languages, Albaha University, Al-Baha, Saudi Arabia

Corresponding Author: John Kuriakose, E-mail: johnkuriakose59@gmail.com

\section{ARTICLE INFO}

Article history

Received: December 12, 2017

Accepted: March 12, 2018

Published: April 30, 2018

Volume: 9 Issue: 2

Advance access: March 2018

Conflicts of interest: None

Funding: None

Key words: Pluralism,

Universalism,

Allegory,

Hinduism,

Christianity,

Islam,

Karma,

Retributive justice

\begin{abstract}
Yan Martel's Life of Pi - the story as well as its religious ideology - exhibits apparent intertextual correspondence with the concept of "Universalism" the Indian mystic Swami Vivekananda preached to the world more than a century ago. Martel's central character Pi represents this concept of religion, which finds the same set of universally valid principles in all religions of the world, and thus embraces all religions with the willingness to worship God in all places of worship, irrespective of whether they belong to Islam or Christianity or Buddhism or Hinduism. This perception of religiousness of Life of $P i$ comes as a solution to the concerns of the present religiously divided, material and greedy world that speaks a lot in vain about ecumenism, interfaith and constructive interaction among religions. The story of the shipwreck with the horrible experiences of $\mathrm{Pi}$ in the lifeboat in the presence of the Indian tiger Richard Parker and his eventual survival validates this concept of God and works out a formula for a harmonious coexistence of religions and other conflicting forces in the world. Thus the book becomes a great religious allegory in tune with the fundamentals of all religious traditions: a pilgrimage on the sea of Karma to be united with the Absolute, a metaphor of the Atman seeking to realize Brahman, and an allegory on the concept of retributive justice of God by which sins are punished and virtues rewarded.
\end{abstract}

\section{INTRODUCTION}

This article focuses on the concept of religiousness exemplified in Yan Martel's Life of Pi, and attempts to uncover how it corresponds with the religious philosophy the Indian mystic Swami Vivekananda posited before the world more than a century ago. It traces the ideological content of the novel into Vivekananda's concept of "universalism" (Bhajanananda, 2008, p. 27), and illustrates that Martel's central character Pi's acceptance and practice of three religionsHinduism, Christianity and Islam-have their counterparts in the religious ideology of Swami Vivekananda.

The story of the catastrophic voyage of Pi with his parents and brother for immigrating to Canada might be a product of the diverse life experiences of Martel who was born in Spain, but was intellectually and culturally shaped in Africa, Europe, South America, North America and Asia. And the new concept of religious unity with the idea of oneness of God of his book might have been triggered by the numerous instances of communal violence the world witnessed in the last quarter of the twentieth century in different parts of the world. Also, Martel chose India as the spiritual as well as physical terrain of his book, obviously because he was fascinated by its mysticism and the uniquely multireligious and multicultural social fabric. In his "author's note," he tells his reader beforehand (as a metafictional strategy) that it was a waiter in an Indian Coffee House in the Indian town Pondicherry who told him the story "that would make one believe in God." And it is in that story that we read about the Indian Brahmin boy Piscine Molitor Patel--who is later called Pi, and then Mr. Patel--who accepts Christianity and then Islam while being a Hindu, and leads a perfectly satisfied, pious and spiritual life by practicing all these religions.

\section{PLURALISM AT PRESENT AND THE RELEVANCE OF LIFE OF PI}

Modern world speaks a lot about constructive interaction among religions. Today, a lot of discussions are around in favour of religious pluralism. In America, even though efforts are being made to preserve and enrich "America's Sacred Ground" by ensuring equal dignity for all religions and by bridging differences (McGraw, 2005), such efforts do not go 
beyond "pretentions to religious inclusion" (Beneke, 2006, p. 4). With the Second Vatican Council of 1963-65, the Catholic Church changed its attitude of contempt towards Jews and Muslims, and decided to work together with them on the ground that all these religions were rooted in the worship of one "true God," and consisted of "Abrahamic people." But even for such an attitudinal change, in the Church, there were both "weepers and cheerers;" and for the "weepers, those who remain outside their faith are in the grip of "invincible ignorance" (D'Costa, 2014, pp. 1-4). As each of these Abrahamic religions is rooted on its own exclusive foundation, it is incapable of merging its faith with another, and hence, for all of them, the question of accepting other religions like Hinduism is something unthinkable. For instance, as D'Costa observes, “Christian language about God is necessarily rooted in the shape of Jesus' life, death, resurrection, the outpouring of the Holy Spirit; and the formation of the Christian community is centered on the risen Christ. In theological terms, the trinity is the foundation of the church, or more elaborately: Christocentricism, pneumacentricism, and ecclesiocentricism are inextricably related"' (D'Costa, 2009, p. 11). Hence, those religions who do not accept these Christian fundamentals are bound to be kept away from Christian places of worship and vice versa. Similarly, even though pluralists are inclined to accept that all religions -- Christianity, Judaism, Islam, Hinduism, Sikhism, Buddhism, Taoism-- are "different culturally conditioned responses to the Transcendent" (Hick, 1997, p. 161), Christians hold the view that Christianity alone is fully true and salvific. And the Islamic position, according to Muttahari, is that "Non-Muslims who believe in God and the hereafter and do good deeds with the intention of seeking nearness to God, on account of being without the blessing of Islam, are naturally deprived of benefiting from [its] Divine program" (p. 96). However, according to him, it reserves some acceptance for the good deeds of such people. Muttahari thus concludes: ".that proportion of their good deeds is accepted which is in accordance with the Divine program, such as forms of favours and services to God's creation" (p. 96). Each religion, thus, has built and is guarding its own stronghold of 'true faith.'

Sree Ramakrishna and Swami Vivekananda, more than a century ago, preached to the world the message of universal religion, and proved that principle by practicing it in their own lives. They taught that all religions of the world do one and the same thing: show us "the way to become perfect" (Vivekananda, p. 215). They also proved in their own lives that it is possible for a Hindu to be a Christian or a Muslim without renouncing Hinduism.

After the days of Vivekananda, it was Raimon Panikkar, the Christian priest turned Hindu-Christian theologian who voiced a similar religious stance. For him, his life was a pilgrimage of which he said: 'I 'left' as a christian, I 'found' myself a hindu, and I 'return' a buddhist, without having ceased to be a Christian" (Panikkar, 1999, p. 42). He was able to live as a Christian, a Hindu and a Buddhist at the same time. In his view, "in the present world context, one can hardly fail to discover positive and true values--even of the highest order outside of one's own tradition" (p. 6). According to him, for making such a development possible, what is needed among different faiths is not a "dialectical dialogue," but a "dialogical dialogue;" when the former makes "winners and losers," the latter "changes the partners themselves," while shedding some new light on the subject (p.38).

Today, pluralism becomes a political slogan addressing the question, how to be at peace with other faiths. Scholars are also aware of the practical difficulties of polytheism. Hick asks: "Does the Holy Trinity preside over Christian countries, Allah over Islamic countries, Vishnu and Shiva over different parts of India? And what about the increasing number of places in which more than one religion is practiced?" (Hick, 1997, p. 165).

It is in such a world scene that Yan Martel's Life of Pi comes in with the character Pi who not only accepts other religions, but also practices all of them. Pi's life thus becomes a pilgrimage across the religious traditions of the world, knocking down the age-old mighty walls of prejudices stuck between them.

\section{SWAMI VIVEKANANDA'S CONTRIBUTIONS TO RELIGIOUS PLURALISM}

Swami Vivekananda, the Indian mystic, was the first to declare to the world that God is one, and that all religions, irrespective of their names, places of origin and forms of worship "show us the way to become perfect." He said: "Churches, doctrines, forms, are the hedges to protect the tender plant, but they must later be broken down that the plant may become a tree. So the various religions, Bible, Vedas, dogmas - all are just tubs for the little plant; but it must get out of the tub. Nishthâ is, in a manner, placing the plant in the tub, shielding the struggling soul in its path (Vivekananda, p. 1821). On 28 June 1895, during his teachings on Gita, he said: "Real religion is one, but we quarrel with the forms, the symbols, the illustrations" (p. 1829). And he emphasized the view that when God is one and the same, it is only ignorance that makes religions convert people to their faiths.

Further clarifying this concept in a personal way, he said: I accept all religions that were in the past, and worship with them all; I worship God with every one of them, in whatever form they worship Him. I shall go to the mosque of the Mussalman; I shall enter the Christian's church and kneel before the crucifix; I shall enter the Buddhist temple, where I shall take refuge in Buddha and in his law. I shall go into the forest and sit down in meditation with the Hindu, who is trying to see the Light which enlightens the heart of everyone. Not only shall I do all these, but I shall keep my heart open for all that may come in the future. (qtd. in Sharma, 2013, p. 44)

About this open-minded and unprejudiced religious stance of Swami Vivekananda, Swami Bhajanananda has recorded as follows:

The desire to realize God through other religions became strong in him and, two years later in 1866 he began to follow the Sufi path of Islam under a Sufi guide. He lived like a Muslim, offering Namaz and repeating the name of Allah. This sàdhanà culminated in the vision of a radiant Being who finally merged into the Absolute. Eight years later, the desire to realize God through the 
spiritual path of Christianity became strong in him, and he began to listen to readings from the Bible. (Bhajanananda, 2008, p. 11)

On 11 September 1893, addressing the Parliament of Religious held in Chicago, representing Hinduism, Swami Vivekananda declared to the world: "We believe not only in universal toleration, but we accept all religions as true." Following this, he quoted the words of Krishna referring to the doctrine of Gita: "Whosoever comes to Me, through whatsoever form, I reach him; all men are struggling through paths which in the end lead to me." And before the great assembly of the representatives of religions from all parts of the world, he placed the following prayer to God, which he inherited from his guru Sri Ramakrishna: "As the different streams having their sources in different places all mingle their water in the sea, so, O Lord, the different paths which men take through different tendencies, various though they appear, crooked or straight, all lead to Thee" (Vivekananda, p. 31).

On 19 June, 1895, Swami Vivekananda taught his disciples from the Bible, from the "Book of John." He read out the text, "In the beginning was the Word, and the Word was with God, and the Word was God." Then he explained it to his disciples; the word "Word" in the "Book of John" he equated with the concept of "Mâyâ" in Hinduism, which means "manifestation of God." Of its two manifestation, he said, one is general, and the other "the special one of the great Incarnations of God - Krishna, Buddha, Jesus and Ramakrishna. He believed and taught his disciples that Christ is one among the different incarnations of God- "the special manifestation of the Absolute." And for him, the twenty-ninth verse in the "Book of John," " "taketh away the sin of the world' means that Christ would show us the way to become perfect." He said: "God became Christ to show man his true nature, that we too are God. We are human coverings over the Divine; but as the divine Man, Christ and we are one.The Christ who is the Incarnation of God, who has not forgotten His divinity, that Christ can help us, in Him there is no imperfection" (Vivekananda, p. 215).

In the address he made on 15 September 1893 to the Parliament of Religions in Chicago he introduced himself as a Hindu, and publicly confessed: "I am sitting in my own little well and thinking that the whole world is my little well." And he said, like the Hindu, "the Christian sits in his little well and thinks the whole world is his well. The Mohammedan sits in his little well and thinks that is the whole world" ( $p$. 325). And he pleaded with the whole assembly to break down all such barriers. In the speech, he also referred to the doctrine of love preached in the Vedas and reiterated by Krishna who Hindus believe to be as God incarnate on earth.

\section{THE ALLEGORY AND THE SHIPWRECK METAPHOR}

Life of $P i$ is a religious allegory. The voyage of Tsimtsum and its wreck, in terms of Hindu philosophy, is a metaphor of the pilgrimage of Atman seeking to realize Brahman. The ship, the ocean and all other things including humans as well as other forms of life on the land and in the sea are parts of
Brahman. The voyage is the pilgrimage taking place on the sea of Karma, and Pi's father, mother, brother and Pi himself are pilgrims. On the pilgrimage, the "liberation account" of each one has to be credited or debited on the basis of his/her actions; in the case of Pi's father, mother and brother, it gets debited, whereas for Pi alone, it gets credited.

This allegorical undertone of the story is in tune with the religious philosophy of the Abrahamic religions Judaism, Christianity and Islam as well. All these religions believe in the retributive justice of God, which rewards virtues and punishes sins. The symbolic voyage begins in Chapter 37, "The Pacific Ocean," with the abrupt announcement, "the ship sank" (p. 97). This announcement comes as if something that is predestined has come true. Was it the will of God? Pi's father, the "earthbound" businessman" who is not religious and "who gets his animals blessed by a priest for the success of his business," his mother who is "bored and neutral on the subject [of religion]," and his brother Ravi for whom religion is no better than the game of cricket are all swallowed by the ocean. And Piscine, the true believer, alone survives!

The Book of Matthew in the Bible says: "Blessed are they that mourn: for they shall be comforted. Blessed are the meek: for they shall inherit the earth. Blessed are they which do hunger and thirst after righteousness: for they shall be filled. Blessed are the merciful: for they shall obtain mercy. Blessed are the pure in heart: for they shall see God. Blessed are the peacemakers: for they shall be called the children of God. (Book of Matthew, Chapter 5: 4-9). The life and actions of $\mathrm{Pi}$, throughout the book, are in agreement with the above conditions for being blessed. He loves everyone, hates none, and is in perfect harmony with everything in the world; whereas his father is selfish and greedy, and his mother and elder brother Ravi also share his father's views. However, Pi loves his parents and brother intensely. Left all alone in the lifeboat, and in the precarious presence of the tiger, pining for his dear ones, he cries out: "Mother, my tender guardian angel of wisdom, where are you? And you, Father, my loving worrywart? And you, Ravi, dazzling hero of my childhood. Vishhu preserve me, Allah protect me, Christ save me, I can't bear it! Treeeeee! Treeeeee! Treeeeee!" (Martel, 2001, p. 97-98).

The story can be read in parallel with the Book of Job and the Book of Jonah in the Bible. Jonah the prophet who was sent to Ninevah by God, was caught in the storm, cast overboard by shipmates, swallowed by the fish, and then vomited out on the shore of Ninevah for preaching to Ninevites for their repentance, and thus to fulfill the will of God. The similarity between the ordeal of Jonah and that of $\mathrm{Pi}$ is apparent: both are thrown into the sea as per the will of God. When Jonah spends three days in the stomach of the fish, Pi spends 227 days in the lifeboat-- both, eventually, to be emptied on the shore to perform the will of God. On the land, Jonah preaches to the Ninevites urging them to repent their sins, and $\mathrm{Pi}$, on the newfound land, practices spirituality, spreading the message of universal religion.

Life of $P i$ is also an investigation of Divine justice, as in the Book of Job of the Bible. As in Job, Pi also addresses the question, 'Why do the virtuous suffer?' In both Job and 
$P i$, we find God rewarding virtues and punishing sin. Job, the "servant of God" (1:8) in spite of his being "perfect and upright, and one that feared God, and eschewed evil" (1:1), is being tested by God. He loses everything - his sons and daughters, livestock, servants and house. However, he holds on to his faith till the very end, and says: "Naked came I out of my mother's womb, and naked shall I return thither: the LORD gave, and the LORD hath taken away; blessed be the name of the LORD" (1:21). Similarly, Pi is deprived of everything in his life; yet, he continues to have faith in God to the very end of his ordeal. And in both cases, finally, God restores all blessings on His servants: in the case of Job, "the LORD blessed the latter end of Job more than his beginning (42: 12); and in the case of Pi, God blessed his life in Toronto with all happiness, with a loving wife and loving children.

The struggle involving animals - zebra, orangutan, hyena and Richard Parker in the lifeboat-- may be read as the present-day conflict among religions, one trying to overpower and destroy another, and of them, Richard parker becoming the victor. Pi's survival struggle in the lifeboat with Richard Parker symbolizes the emotional conflict he endured to harmonize his faith with the world that is religiously rifted, and the floating island with its fantastic details are the pitfalls on the course of life. Later, Pi's painful separation from Richard Parker stands for his getting completely detached from all religious prejudices. And the description of his house in Toronto as a temple with images of Ganesha, Lord Shiva, wooden cross, Virgin Mary, Kaaba, Quran, Bible and with various article of devotion symbolically sums up the spiritual theme of the book - espousal of all religions.

\section{INTERRELIGIOUS-INTERTEXUAL DIALOGUE: LIFE OF PI AND SWAMI VIVEKANANDA}

Life of Pi places before the world a new perception of religiousness that embraces all religions with a concept of God which could resolve the problems of the present religiously divided, material and greedy world. The new religious outlook typified by the character of $\mathrm{Pi}$, who in spite of opposition from every quarter and even from within his own family, is commendably presented in the story. While being a Hindu, Pi never preaches the merits of his faith over other faiths; rather, he embraces all faiths with due respect and admiration for each one. His attitude and approach to the tiger Richard Parker, fully knowing that the existence of the animal in the boat puts his own existence at stake, also reveals how harmonious existence is possible among different species. It symbolically works out a brilliant formula for religious harmony too.

The Indian Hindu boy from a very traditional and conservative social and religious setting has nothing about him to be the hero of a novel; it is only when he accepts and begins to practice other religions, he assumes the proportions of a hero. The reader, as he moves from page to page, finds in them an entirely new concept of religiousness in the context of some most excruciating experiences in the boy's life. The victory — spiritual as well as physical — of $\mathrm{Pi}$, is heroic in the sense Swami Vivekananda used the term "Vira." Swa- mi used this expression for explaining to his disciples his concept of true heroism; he said: "Vira, the Sanskrit word for "heroic," is the origin of our word "virtue," because in ancient times the best fighter was regarded as the most virtuous man" (Speeches 46). The victory of Pi is not a conventional victory; it does not conquer enemy's land or wealth or anything else that is worldly precious. Neither his actions nor his prayers are for any such gains. He is a real Bhakta in the sense Swami Vivekananda explained the word to his disciples. Swami said: "The idea of asking God for anything is sacrilege to a Bhakta. He will not pray for health or wealth or even to go to heaven. One who wants to love God, to be a Bhakta, must make a bundle of all these desires and leave them outside the door and then enter (Vivekananda, p. 1870). On symbolic terms, when the ship in Life of Pi wrecks, everything that is lost - thrown into the sea-is the whole bundle of material desires of Pi's father. Thus Pi reminds us of the following words of Vivekananda:

"These prayers for health and wealth and material prosperity are not Bhakti. They are the lowest form of Karma. Bhakti is a higher thing. We are striving to come into the presence of the King of kings. You read in the Bible that Jesus drove the buyers and sellers out of the temple. So it goes without saying that the first task in becoming a Bhakta is to give up all desires of heaven and so on. Such a heaven would be like this place, this earth, only a little better. The Christian idea of heaven is a place of intensified enjoyment. How can that be God? All this desire to go to heaven is a desire for enjoyment. This has to be given up. The love of the Bhakta must be absolutely pure and unselfish, seeking nothing for itself either here or hereafter." (Vivekananda, p. 1870)

Anne M. Todd's observation on Hinduism seems to be relevant to the character of $\mathrm{Pi}$; in her view, "Hindus accept other religions, including Christianity, Judaism, and Buddhism, without feelings of superiority. This tolerance is obtainable because Hindus believe that all religions lead to finding truth for the soul. How each soul finds that truth (and to what god a person prays in order to find it) is not as important as reaching the truth" (Todd, 2004, p. 8).

When the world talks about the need of pluralism for the sake of peaceful coexistence or for diversity's sake, Pi's religious stance stands out as unique. It is neither "an attitude of enthusiastic endorsement of pluralism for the diversity's sake" as Sorin Baiasu recommends (Baiasu, 2011, p. 80), nor a "modus Vivendi" as John Horton speaks about (Horton, 2011, p. 120-136). Also, it is not a political or diplomatic comprise with other religions. It is rather a way of completely surrendering to God, the same God he believes all religions represent, irrespective of the differences in their rituals and practices.

None of the terms that contemporary theologians use-“exclusivism," "inclusivism," "parallelism," "interpenetration" and "pluralism" (Panikkar, 1999, p. 7) would precisely explain the theological stance of Martel's Pi. The boy shares other faiths not because he finds Hinduism far from being perfect, and not for the sake of being at peace with them either. Then what kind of a religious stance does 
Pi represent? Unlike the exclusivists, inclusivists, parallalists, interpenitrationists and pluralists of our time, Pi simply embraces all the religions he has come across, without considering or identifying one as 'his' and others as 'theirs.' He doesn't find one religion above another in any respect, and hence, practices each one with the same fervour. And I believe he wouldn't hesitate to accept a fourth one too, if he comes across one.

Chapter 16 of Life of $P i$ is in fact a discussion on the concept of God and religion the book presents. It begins by stating that we are all born without religion. And then, someone introduces us to God and then religions with their rituals. The names of the religions and their rituals might differ, but God is the same for all. Thus a "Hindu feels at home" in the temple, a Muslim in the mosque, a Christian in the Church. Now Pi refers to the concept of Brahman and Atman in Hinduism. Brahman, the "world soul" is manifested in two forms: Brahman nirguna and Brahman suguna. Brahman Nirguna is identified as "One, Truth, Unity, Absolute, Ultimate Reality, and Ground of Being" (Martel, 2001, p.48). Brahma suguna is identified as Shiva, Krishna, Shakti, Ganesha; and we attribute to them the qualities love, mercy and fear. Brahman is found in man as well as all other forms like animals, plants and earth.

Chapter 17 of the novel details how, in Munnar, the boy Piscine becomes a Christian. In this Chapter, Martel introduces the theme of religious pluralism, and describes how the fourteen year old boy comes to accept Christianity. It also presents Hinduism as a religion that is always willing to embrace other faiths. About his first visit to the Christian church in Munnar, Piscine says: "I first heard of the tremendous, cosmic might of loving kindness in this Hindu land. It was Lord Krishna speaking. I heard him, and I followed him. And in his wisdom and perfect love, Lord Krishna led me to meet one man. I was fourteen years old, and a well-content Hindu on a holiday when I met Jesus Christ" (p.50). After spending three days in the Christian church and seeing there the crucified figure of the bruised, bleeding God, who by his death paid for the sins of the sinners, and after spending three days thinking about Christ, just before leaving the place he says to the priest, "Father, I would like to be a Christian, please." And the father replies to him, "You already are, Piscine - in your heart. Whoever meets Christ in good faith is a Christian. Here in Munnar you met Christ" (p. 57). And the chapter concludes with the following words of Pi: "I entered the church, without fear this time, for it was now my house too. I offered prayers to Christ, who is alive. Then I raced down the hill on the right to offer thanks to Lord Krishna for having put Jesus of Nazareth, whose humanity I found so compelling, in my way" (p. 58). Thus, it is not conversion from Hinduism to Christianity that is taking place here; rather, the boy is embracing Christianity — its humanity — while being a Hindu.

Chapter 18 of the novel tells the reader about the boy becoming a Muslim, at the age of 15 . While exploring his hometown, Pi meets a devout poor Muslim--a Sufi mystic. In Chapter 19, to the boy's question, "What's your religion about?" the man replies, "It is about the beloved" (p. 60). And the boy finds it "a beautiful religion of brotherhood and devotion." There he listened to the imam, and then he joined the worshippers in prayer. The chapter concludes as follows: "I felt good to bring my forehead to the ground. Immediately it felt like a deeply religious contact" (p. 61). In Chapter 20, the Sufi Muslim mystic tells him: "If you take two steps towards God," "God runs to you" (p. 61). About this Sufi Muslim Satish Kumar's recitals of the holy book, he says: "It was not wide, just one man's voice, but it was as deep as the universe. I described Mr. Kumar's place as a hovel. Yet no mosque, church or temple ever felt so sacred to me" (p. 62). About the experience of praying with Mr. Kumar the Sufi mystic, he remarks: "I knelt a mortal; I rose an immortal. I felt like the center of all circle coinciding with the centre of a much larger one. Atman met Allah" (p. 62).

We find Martel ironic and even satiric about the narrow-mindedness of the representatives of religions. For the Christian priest, "Piscine is the good Christian boy," for the imam, "He's a good Muslim boy," and for the pandit, "He's a good Hindu boy" (p. 66). Each of them expects a person to have only one religion. For the imam, "Hindus and Christians are idolaters. They have many Gods." For the pundit, "Muslims have many wives." For the Christian priest, "there is salvation only in Jesus." And the pundit says, "Christians know nothing about religion." "They strayed long ago from God's path." When Christians looked for miracles, Muslims "stick to the essential miracle of existence." They would say, "Birds flying, rain falling, crops growing - these are miracles enough for us" (p. 67). The heated debate among these men of religions continued with allegations and accusations, and with counter-allegations and counter-accusations.

In Chapter 25 of the novel, the narrator calls the attention of the reader to the religious hypocrisy of people: for them, the sight of "a widow deformed by leprosy begging for a few paise" is "business as usual." But they would not stand "a slight against God;" it would make "their faces go red, their chests heave mighty, they sputter angry words" (p. 70). The narrator comments:

"These people fail to realize that it is on the inside that God must be defended, not on the outside. They should direct their anger at themselves. For evil in the open is but evil from within that has been let out. The main battlefield for good is not the open ground of the public arena but the small clearing of each heart. Meanwhile, the lot of widows and homeless children is very hard, and it is to their defense, not God's that the self-righteous should rush." (p. 71)

And in this connection, Mr. Patel recalls the sour experiences he had from mosque, church and temple, for his differing from their ways of practicing religion. He says:

"Once an oaf chased me away from the Great Mosque. When I went to church the priest glared at me so that I could not feel the presence of Christ. A Brahmin sometimes shooed me away from darshan. My religious doings were reported to my parents in the hushed, urgent tones of treason revealed. As if this small-mindedness did God any good. To me religion is about our dignity, not our depravity. I stopped attending mass at our Lady of Immaculate Conception and went to Our Lady of Angels. I no longer lingered after Friday prayer among my 
brethren. I went to temple at crowded times when the Brahmins were too distracted to come between God and me." (p. 71)

The conflict in the story begins with his father's decision to leave India for Canada. Even though Pi loves his father, he mentions him as "a New India-rich, modern and as secular as ice cream" who "didn't have a religious bone in his body" (p. 65). He was an "earth bound" businessman, who gets his animals blessed by a priest for the success of his business, not for his soul. "Spiritual worry was alien to him;" his worry was only financial. Piscine's father the materialist feels urgency to leave his country in search of material success, and it is this craving for material wealth that throws his entire family into the ocean in order to perish. The mention of Mrs. Gandhi and the political turmoil in India in her time serve only to trigger the decision of the family to leave India for Canada. But this is ironic: Piscine's father who is already rich by Indian standards, yet leaving his country for better fortunes, is in fact leaving a land of safety and entering a sea of troubles. The boy loved his mother so much, yet in his estimate, she was "impious" and his brother Ravi, not religious too.

Chapter 26 of the novel places before the reader the fundamental religious question the book raises: Is it possible for a man to be a Christian, Muslim and Hindu at the same time? In answer to Piscine's request, "I would like to be baptized and I would like a prayer rug," he receives from the Christian priest only a question, "A What? What?" (p.71). In answer to the priest's query, "Why do you want to pray outside? In fact, why do you want to pray at all?" when Piscine says, "Because I love God," the priest seems "taken aback." When Piscine says, "But I want to pray to Allah. I want to be a Christian," the priest responds, "You can't be both. You must be either one or the other." And when the boy asks, "Why can't I be both?" the priest replies, "They are separate religions! They have nothing in common" (p. 72). His mother also tells him the same: "Listen, my darling, if you're going to be religious, you must be either a Hindu, a Christian or a Muslim. You heard what they say in the esplanade" (p. 73). But he asks her, "I don't see why I can't be all three. Mamaji has two passports. He's Indian and French. Why can't I be a Hindu, a Christian and Muslim?" (p. 73).

Martel builds up his book's concept of religion meticulously in his description of Mr. Patel's house in Toronto, by drawing themes from the three religions-- Hinduism, Christianity and Islam. Martel describes the house as "a temple." In the entrance hall there is a framed picture of Ganesha; on the opposite wall, there is a picture of wooden cross; in the living room, on a table, there is picture of Virgin Mary; next to it, there is a framed photo of Kaaba, the holy sanctum of Islam; on the television set, there is a statue of Lord Shiva; and in the kitchen, there is a shrine with the pictures of Ganesha, Krishna and the images of Lakshmi, Shakti, the mother goddess, in the form of Parvati, and the stone shiva yoni linga, the Hindu symbol representing the male and female energies of the universe etc. And also there are "various articles of devotion" which form a part of Hindu faith. Upstairs, in his office, there is a brass Ganesha, a wooden Christ on the cross on the wall, a green prayer rug, a book covered by a cloth with an Arabic word that means God at its centre, and a Bible on the bedside table. Then, a prayer rug, on a bookstand the Quran covered by a cloth, and on the bedside table, the Bible. In short, what the reader finds in Patel's house is a holy brotherhood of religions - different incarnations of the one and the same God dwelling the heart of $\mathrm{Pi}$ in perfect harmony.

$\mathrm{Pi}$ admits that he became a Hindu and believed in its rituals even before he knew anything about it. He says: "If you ask me how Brahman and Atman relate precisely, I would say in the same way the Father, Son and the Holy Spirit relate: mysteriously." And he believes "Atman seeks to realize Brahman, to be united with the Absolute," and it is a pilgrimage along "the Bank of Karma." And on this bank of Karma, "the liberation account of each of us is credited or debited depending on our actions" (p. 49). And then he concludes: "This, in a holy nutshell, is Hinduism, and I have been a Hindu all my life" (49). But he says, "We should not cling! A plague upon fundamentalists and literalists!" (p. 49).

In Chapter 20 of the novel, Mr. Patel describes his experience of having a vision of Virgin Mary, in Canada, on a sunny winter day, with meticulous details. He says: "I felt I saw her, a vision beyond vision. I stopped and squinted. She looked beautiful and supremely regal. She was smiling at me with loving kindness. After some seconds she left me. My heart beat with fear and joy. The presence of God is the finest of rewards" (pp. 62-62).

The discussion on anthropomorphism and zoomorphism in Chapter 32 attributes human characteristics to animals and brings them to the level of humans. Patel's religion finds even animals worthy of being loved like humans, as they are also God's creations. The coexistence of man and beast in the lifeboat for months on is an exemplification of this thesis. The presence of the ferocious beast in the lifeboat happens as a divine plan for saving the life of $\mathrm{Pi}$. The boy is conscious about the irony of his act of saving the animal, but his faith in God compels him to do so. Here we find the thrill of a human in being religious even at the cost of his life. Later, it turns out that it is the animal that helps him survive, while being left to the catastrophic struggle with the Pacific.

Pi's spirituality, no doubt, is Indian; it comes very close to Swami Vivekananda's concept of universal religion. However, it is more inclusive, yet simpler than the concept of reli gion Vivekananda preached and practiced. As for Vivekananda, for Pi too, Hinduism, Christianity and Islamin fact, all religions-- would take man to the same God. Pi's concept of religion has no philosophical abstraction, yet it is much more inclusivist and more liberal than that of Vivekananda. Pi not only respects and accepts other faiths, but 'lives' as a Hindu-Christian-Muslim with their "rituals and doctrines."

Evidently, Martel took the subject of his book from India, for he has acknowledged the fact that he came to India for writing a story, and that he got its subject from a waiter in an Indian Coffee House in Pondicherry. Also, it is a fact known 
to the world that India is a country where all major religions - Hinduism, Islam and Christianity - have been coexisting in harmony for ages. Furthermore, the characters and situations in the book are mostly Indian; and the story of the Hindu boy following the Sufi path of Islam inspired by a Sufi man, his living like a Muslim offering regular Namaz, and going through the spiritual path of Christianity bears close parallel to Swami Bhjrananda's account of similar experiences in the life of Swami Vivekananda and his guru Sree Ramakrishna.

The vision of Virgin Mary which Mr. Patel claims to have had in Toronto, in Chapter 20 also corresponds to similar experiences of Swami Vivekananda and Sree Ramakrishana. Jyothirmaya Sharma has recorded in his book about Vivekananda's acceptance of Jesus as the incarnation of the Abslolute: "Some time in 1874, once when he was looking at a picture of Madonna with infant Jesus, he became completely absorbed in the thought of Christ. This inner absorption was so intense that for three days he could not go to the temples or think of Hindu deities. At the end of this period he had a wonderful vision of Jesus Christ which finally merged in the experience of the Absolute" (Sharma, 2013, p.11). Vivekananda's guru Sree Ramakrishna also had acknowledged his acceptance of other religions. Sharma has recorded in his book that Sree Ramakrishana "could realize God through Islamic and Christian paths in such a short time." (p. 12).

Vivekananda's concept of vegetarianism also has permeated Martel's novel. In his speech on practical Vedanta, which he delivered in London on 10 November 1896, he said:

"I myself may not be a very strict vegetarian, but I understand the ideal. When I eat meat I know it is wrong. Even if I am bound to eat it under certain circumstances, I know it is cruel. I must not drag my ideal down to the actual and apologize for my weak conduct in this way. The ideal is not to eat flesh, not to injure any being, for all animals are my brothers. If you can think of them as your brothers, you have made a little headway towards the brotherhood of all souls, not to speak of the brotherhood of man! (Vivekananda, p. 625)

It is this Vivekanandan model that we find in $\mathrm{Pi}$. He is a Hindu Brahmin and a vegetarian; but as Vivekananda has said, "Under certain circumstances" - left all alone in the sea, with the tiger Richard Parker, he is forced to compromise his vegetarianism for his survival. He kills and eats fish and turtles and drinks their hot blood for his own survival and that of his companion Richard Parker. But on reaching the land of safety, he returns to the practice of vegetarianism.

The following statement of Vivekananda is very relevant to this context: "There never was my religion or yours, my national religion or your national religion; there never existed many religions, there is only the one. One Infinite Religion existed all through eternity and will ever exist, and this Religion is expressing itself in various countries, in various ways" (Vivekananda, p. 1000).

\section{CONCLUSION}

Yan Martel's novel Life of Pi bears strong intertextual correspondence with Swami Vivekananda's concept of "uni- versalism," which finds the same set of universally valid principles in all religions. The story as well as its concept of religiousness exhibits this ideology that embraces all religions with the willingness to worship God in all places of worship, irrespective of whether they belong to Islam or Christianity or Buddhism or Hinduism. In the present world which speaks a lot about ecumenism, interfaith and a constructive interaction among religions, Life of $\mathrm{Pi}$ presents before the reader a new perception of religiousness by embracing all religions with a concept of God that could address the concerns of the present religiously divided, material and greedy world. The shipwreck and the horrible experiences of $\mathrm{Pi}$ in the lifeboat and his eventual survival in the presence of the Indian tiger Richard Parker validate this concept of God and work out a formula for religious harmony and a peaceable coexistence of conflicting forces in the world. Thus Pi qualifies himself for the title "vira" (hero), the Sankrit term Swami Vivekananda applied only to a virtuous person, in the sense, a real Bhakta who prays to God not for wealth or health or for the joy of being in heaven. And the book thus becomes a religious allegory that is in tune with the fundamentals of all religious traditions: a pilgrimage on the sea of Karma to be united with the absolute, a metaphor of the Atman seeking to realize Brahman, and an allegory on the concept of retributive justice of God under which sins are punished and virtues rewarded.

\section{REFERENCES}

Baiasu, Sorin. "Dealing Morally with Religious Differences." Democracy, Religious Pluralism and the Liberal Dilemma of Accommodation. (Ed.), Monica Mukherjee. London: Springer, 2011. pp. 77-101.

Beneke, Chris. Beyond Toleration: The Religious Origins of American Pluralism. Oxford: Oxford University Press, 2006.

Bhajanananda, Swami. Harmony of Religion from the Standpoint of Sri Ramakrishna and Swami Vivekananda. Kolkata: Ramakrishna Mission Institute of Culture, 2008.

D'Costa, Gavin. Catholic Doctrines on Jews and Muslims. Oxford: Oxford University Press, 2014.

D’Costa, Gavin. Christianity and World Religions: Disputed Questions in the Theology of Religions. West Sussex: Wiley-Blackwell, 2009.

Hick, John. The Possibility of Religious Pluralism: A Reply to Gavin D'Costa. Source: Religious Studies, Vol. 33, No. 2 (Jun., 1997), pp. 161-166 Published by: Cambridge University Press http://www.jstor.org/stable/20008088

Horton, John. "Modus Vivendi and Religious Conflict." Democracy, Religious Pluralism and the Liberal Dilemma of Accommodation. (Ed.), Monica Mukherjee. London: Springer, 2011. pp. 120-136

Martel, Yan. Life of Pi. Delhi: Penguin Books, 2001.

McGraw, Barbara A., Formicola, Jo Renee. Taking Religious Pluralism Seriously: Spiritual Politics on America's Sacred Ground. Texas: Baylor University Press, 2005.

Mutahhari, Ayattullah Murtadha. Islam and Religious Pluralism. (Trans.), S. Sulayman

Ali Hasan. Federation of Khoja Shia Ithna-Asheri Muslim Communities, UK., 2005. 
Panikkar, Raimon. The Intra-religious Dialogue. New Jersey: Paulist Press, 1999.

Sharma, Jyothirmaya. A Restatement of Religion: Swami Vivekananda and the Making of Hindu Nationalism. New Haven \& London: Yale University Press, 2013. The King James Version of the Hebrew Bible. http://www. davince.com/bible
Todd, Anne M. Spiritual Leaders and Thinkers: Mohandas Gandhi. Philadelphia: Chelsea House, 2004.

Vivekananda, Swami. Complete Works of Swami Vivekananda: January 12, 1863-July 4, 1902.http:// cincin na titemple.com/articles/Complete-Works-ofSwami-ivekananda.pdf 